\title{
ОФІЦІЙНИЙ І НЕОФІЦІЙНИЙ ПРАВОПОРЯДОК ЯК ІНСТИТУЦІЙНА ПРОБЛЕМА ПРАВОВОЇ ПОЛІТИКИ СУЧАСНИХ ДЕМОКРАТИЧНИХ ДЕРЖАВ
}

Крижановська О. В.

У статmі досліджено формування офіційного і неофічійного правового порядку, що є логічним наслідком його інституціоналізації. Запропоновано розглядати їх співвідношення не через протистояння, а через стратегію інкорпорації. 3'ясовано, що неофіційний правовий порядок $\epsilon$ первинним по відношенню до офіційного, однак йому може бути надано якості чинності, у результаті чого він перетворюється на офіційний. Таким чином, офіційний правовий порядок $\epsilon$ лише одним із багатьох прошарків реальної інституційної структури правового порядку, яка є набагато складнішою.

Описано три моделі співвідношення офіційного і неофіційного правопорядку: когерентна, в якій існує їх взаємодоповнення і взаємодія; конкурентна, яка визначається низьким рівнем авторитетності офіційного правового

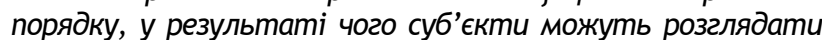
неофіційний правовий порядок як більш надійний; модель протистояння, в рамках якої формується тіньове право як альтернативна правова система, несумісна з офіційним правовим порядком.

Ключові слова: правовий порядок, інфраструктура правопорядку, авторитетність правопорядку, офіційний i неофіційний правопорядок, когерентність, конкурентність, протистояння.

В научной статье исследовано формирование официального и неофициального правового порядка, что является логическим следствием его институционализации. Предложено рассматривать их соотношение не через противостояние, а через стратегию инкорпорации. Уточнено, что неофициальный правовой порядок является первичным по отношению к официальному, однако ему может быть предоставлено качество законности, в результате чего он превращается в официальный. Таким образом, официальный правовой порядок является лишь одним из многих слоев реальной институциональной структуры правового порядка.

Описаны три модели соотношения официального и неофициального правопорядка: когерентная, в которой существует их взаимодополнение и взаимодействие; конкурентная, которая определяется низким уровнем авторитетности официального правового порядка, в результате чего субъекты могут рассматривать неофициальный правовой порядок как более надежный; модель противостояния, в рамках которой формируется теневое право как альтернативная правовая система, несовместимая с официальным правовым порядком.

Ключевые слова: правовой порядок, инфраструктура правопорядка, авторитетность правопорядка, официальный и неофициальный правопорядок, когерентность, конкуренция, противостояние.

The scientific article investigates the formation of an official and informal legal order is the logical consequence of its

Крижановська О. В., 2019 institutionalization. It is proposed to consider their correlation not through confrontation, but through the strategy of incorporation. The idea of structuring comes from the British sociologist $E$. Giddens, and it is expressed in the need to understand social phenomena not from the point of view of representing their objective structure (which does not exist), but from the point of view of their immersion in the subject. In turn, the institutionalization of legal order takes place in four vectors.

The authority and legitimacy of the legal order are interrelated, but not identical, concepts. The authority of the legal order can be represented as its ability to incorporate and supersede the grounds for the actions that the subjects of law use, and thus represent a normative system that is considered to be sufficiently reliable and valuable in representing it to be worth pursuing. Due to the state of trust, the legal order dominates other social regulatory systems. The legitimacy of the legal order may only be relevant in the conditions of its minimum credibility. It is determined through four groups of qualities of legal order: formal, substantive, jurisdictional and procedural. The informal legal order is primary in relation to the official, but it can be given the quality of the validity, as a result, it becomes an official one. Thus, the formal legal order is only one of many layers of the real institutional structure of the legal order, which is much more complicated.

Three models of correlation between official and informal order of law are described: a coherent, in which there is their complementarity and interaction; competitive, which is determined by the low level of authority of the official legal order, as a result of which subjects can consider informal legal order as more reliable; and a model of confrontation, in which, as a rule, shadow law is formed as an alternative legal system, which is incompatible with the official legal order.

Key words: legal order, law enforcement infrastructure, law enforcement authority, official and informal law enforcement, coherence, competitiveness, confrontation.

Постановка проблеми та їі актуальність. Сучасна теорія правового порядку базується на припущені, що правопорядок формується на основі офіційних правил і принципів, які витікають із правової системи. У цьому контексті показовим $\epsilon$ зв'язок правового порядку з законністю, який все ще зберігає свою доктринальну значимість. Законність apriori може бути лише офіційною, оскільки ії зміст і вимоги не можуть бути виведені за рамки діючого законодавства (у вузькому розумінні законність взагалі спрямована на саме законодавство). Здебільшого така ситуація зумовлена ще й тим, що теоретична конструкція правопорядку тісно пов'язана з державою.

Все більш визнаним стає постулат, що правопорядок переважно $\epsilon$ самопродуктивною, відновлюваною соціоструктурою, яка формується передусім за рахунок діяльності окремих індивідів. У цьому сенсі правопорядок може існувати навіть за відсутності держави, 
оскільки його основні інститути можуть бути децентралізованими (наприклад, міжнародний правопорядок). Якщо правовий порядок $\epsilon$ децентралізованим, це означає, що він може формуватися за рахунок широкого кола соціальних джерел, що не можуть бути поставлені у вузькі офіційні рамки.

Сьогодні постає проблема «м'якого» права та його впливу на сучасні правопорядки. М'яке право не $є$ чинним у класичному кельзенівському розумінні чинності (владності), а тому воно не може сприйматися як «право» взагалі. Тим не менш, особливо на рівні національних правових систем різноманітні кодекси саморегулювання у поєднанні зі стандартами, які мають експертне походження тощо, створює ситуацію, коли правовий порядок в окремих своїх сегментах опиняється за межею офіційного правового регулювання, офіційного чинного правового порядку.

Виникає досить суттєва проблема, пов'язана з тим, що з інституційної точки зору такі правопорядки $\epsilon$ авторитетними і легітимними, але при цьому можуть не бути офіційними. Таке бачення правопорядку дозволяє стверджувати, що він може бути неофіційним. У цьому зв'язку постає питання щодо того, чим відрізняються між собою офіційний і неофіційний правопорядки, як і за рахунок чого вони формуються, якими є їхні нормативні основи й інституційні прояви?

Аналіз останніх досліджень і публікацій. Проблема дуалізму офіційного та неофіційного у праві нерідко висвітлювалася в тих чи інших наукових працях. Значний внесок у дослідження правового порядку, a саме розгляду питання щодо формування офіційного і неофіційного правового порядку, реалізовували вітчизняні та зарубіжні вчені, зокрема В.М. Баранов, П. Вестерман, Ф. Гайєк, К.В. Горобець, В.В. Дудченко, В.В. Завальнюк, О.Ю. Калінін, О.Ф. Крижановський, Ю.М. Оборотов, О.О. Уварова, В.О. Четвернін та інші дослідники, які створили методологічну базу осмислення процесів взаємодії між цими двома сторонами правового порядку в сучасних суспільствах.

Метою статті $\epsilon$ дослідження офіційного і неофіційного правового порядку, розгляд їх співвідношення не через протистояння, а через стратегію інкорпорації, виявлення розбіжностей і шляхів формування й інституціоналізації.

Виклад основного матеріалу. Розгляд понять офіційного та неофіційного правопорядків має починатися зі з'ясування того, що дійсно робить той чи інший правопорядок офіційним. Усталений підхід до розуміння правопорядку передбачає, що це «стан відносно усталеної правової впорядкованості (урегульованості i погодженості), захищеності і безпеки правової системи суспільства, який складається в умовах реалізації принципу верховенства права та авторитету закону (законності), тобто це атмосфера (устрій) нормального, сприятливого правового життя суспільства, що встановлюється в результаті здійснення приписів правових норм (виконання дозволів (прав), виконання обов'язків, дотримання заборон) усіма суб'єктами права» [1, с. 504]. Звідси ключовий акцент у розумінні правового порядку робиться на його нормативній природі: це стан упорядкованості, врегульованості, організованості суспільних відносин, який утворюється, існує і функціонує внаслідок фактичної реалізації правових норм відповідно до принципу законності [2, с. 392].
Нормативність традиційно розглядається як підстава для формування правового порядку, що виражає розуміння цього феномену як «засновану на праві та законності впорядкованість суспільного життя, що виражає якісний стан суспільних відносин на певному етапі розвитку суспільства» [3, с. 35]. Однак при цьому загальновизнаною $\epsilon$ теза, що соціальна нормативність має безліч інших форм, які не обмежуються лише правом. Втім правовий порядок базується саме на праві. Загальновідомо, що правовий порядок охоплює правила, які претендують на авторитетність, тобто претендують на те, щоб їм підкорювалися. В цьому сенсі немає жодних сумнівів у тому, що будь-який правовий порядок складається якнайменше із норм. Однак однією з найпроблемніших сфер правової теорії $\epsilon$ те, що одного всеохоплюючого критерію, за яким можна було б відрізнити правову нормативність від інших типів соціальної нормативності, не існує.

У більшості випадків юридична наука пропонує так званий «тест на походження» (pedegree test), метою якого $\epsilon$ з'ясування того, звідки та чи інша норма походить. Якщо з'ясовується, що норма має своїм джерелом компетентний орган держави або ж суб'єкта, який уповноважений державою на видання загальнообов'язкових норм тощо, то така норма $€$ правовою, навіть якщо змістовно вона збігається з моральною чи релігійною нормою. 3 точки зору правової нормативності такий збіг нічого не означає для характеристики норми як правової [4, с. 27-35].

Однак проблема полягає в тому, що тест на походження не $\epsilon$ універсальним. Так, він не спрацьовує у випадку зі звичаєвим правом, що особливо помітно в міжнародному правопорядку, де він зазвичай $є$ одним із двох основних джерел права [5, ст. 38(1)]. Справа в тому, що встановити буквальне походження звичаю не можливо, адже його джерелом є сама практика держав. До звичаю, як сказав Г. Харт, не можливо застосувати аргумент Дж. Остіна, що звичай може стати частиною права лише тоді, коли $є$ відповідна команда суверену, тобто коли юридична сила звичаю визнана державою прямо (через законодавство) чи опосередковано (через його застосування судом). Ця позиція i зараз часто зустрічається в навчальних посібниках і підручниках із теорії держави і права. Проблема полягає в так званому парадоксі звичаю: суд має визнати юридичну силу за звичаєм тоді, коли сторони, які керуються цим звичаєм, вже цю юридичну силу визнали, хоча таке визнання можливе лише через авторитетну команду суверена. Таким чином, «юридизація» звичаю відбувається за принципом хибного кола.

Суб'єкти визнають юридичну силу звичаю через opinio juris до того, як це може зробити держава чи іiі уповноважений орган. Для того, щоб звичай став правовим звичаєм, суб'єкти мають сприймати його таким ще до того, як він таким став. При цьому, якщо суд зможе довести порушення звичаю однією зі сторін, то це означатиме, що встановлюючи звичай і застосовуючи його post factum, суд створить юридичне зобов'язання, якого не могло б існувати в минулому, оскільки звичай юридизовано лише рішенням суду.

Тест на походження не може спрацювати у випадку зі звичаєвим правом. Не спрацьовує він і в тому випадку, якщо використовувати непозитивістський концепт права, а наприклад соціологічний, за яким жод- 
ного формального критерію відмежування права від неправа існувати не може взагалі: правом $€$ те, що тією чи іншою спільнотою вважається системою норм із найвищим рівнем авторитетності і примусовості [6, с. 220]. У цьому випадку в рамках одного суспільства може виникати низка правопорядків, які між собою можуть навіть не перетинатися, і лише один із них буде вважатися офіційним правопорядком, що зовсім не означає, що саме він буде мати найвищу авторитетність для всіх прошарків суспільства і соціальних груп. На цьому особливо загострював увагу $\epsilon$. Ерліх [7, с. 412].

Якщо тест на походження не дає відповіді на питання щодо того, як відмежувати правову нормативність від інших типів соціальної нормативності, то має застосовуватися інший критерій. Із точки зору осмислення офіційного та неофіційного правопорядку ключовою рисою, яка вирізняє правову нормативність, $\epsilon$ iі чинність. Право $€$ чинним, і лише чинність дозволяє констатувати, що заснований на праві правовий порядок $\epsilon$ офіційним. Однак саме поняття чинності сьогодні проходить етап докорінного переосмислення.

За традиційного підходу чинність $\epsilon$ параметром, який приписується правовій нормі за рахунок того, що її ухвалено належним чином і належним суб'єктом. Так, закон $\epsilon$ чинним, якщо його ухвалено парламентом відповідно до процедури, зафіксованої в регламенті, i опубліковано у встановлені законом строки. Зміст закону може суперечити Конституції, однак він втратить чинність тільки тоді, коли Конституційний Суд України визнає його таким [8, ст. 85]. Тобто, чинність $\epsilon$ презюмованою характеристикою правової нормативності, характеристикою, яка формує певний структурований простір офіційного правопорядку. Норми, якіє чинними, породжують офіційний правовий порядок, інституціоналізація якого відбувається в рамках правової системи.

В сучасних публікаціях все більше робиться акцент на тому, що чинність правил та інститутів може бути пов'язана не лише з тим, яким чином вони створені і встановлені, але й із тим, наскільки серйозно до них ставляться, якою $€$ їхня очікувана ефективність. Як зазначає нідерландська дослідниця П. Вестерман, чинність взагалі може існувати без компоненту офіційного визнання якогось правила через його ухвалення парламентом чи видання якимось іншим уповноваженим на це суб' єктом (вона називає такий аспект чинності «вхідним»). Чинність правила може базуватися на тому, що 3 ним рахуються відповідні суб'єкти, навіть якщо це правило взагалі не має офіційного статусу. Прикладами можуть слугувати неофіційні розписки, які виконують функцію векселів на стихійних ринках в Індії, або правила вендети серед мафіозі тощо [9, с. 36-37].

У такому контексті виникає можливість говорити про неофіційне або принаймні недержавне право, яке дає життя відповідному недержавному правовому порядку. 0.О. Уварова вважає, що правове регулювання - це не тільки державне регулювання. $€$ багато недержавних суб'єктів, які створюють і забезпечують дію відповідних правил поведінки. Це громадські організації, політичні партії, торгові об'єднання, релігійні організації, бізнес-асоціації, інтернет-провайдери тощо. Прибічники концепції недержавного правового регулювання вказують на зіткнення різних нормативних спільнот у сучасному світі, в результаті чого соціальна система зазнає як державного, так і недержавного впливу, але жоден із них не є монопольним [10, с. 14]. Це дійсно $€$ серйозним викликом для сучасної правової теорії, яка традиційно націлена саме на осмислення офіційного (державного) права.

На відміну від офіційного права, яке базується на чинності і на цій основі конструюється відповідний правовий порядок, неофіційне (недержавне) право розвивається за рахунок того, що воно:

а) підтримується і реально відтворюється релевантними суб'єктами у своїй діяльності;

б) здатне породжувати наслідки, які $є$ вагомими для суб'єктів і які можуть набути юридичного характеру.

П. Вестерман називає це поточною та вихідною чинністю [9, с. 46], однак К.В. Горобець припускає, що тут коректніше говорити не про чинність, а про авторитетність відповідних правил [11, с. 50]. Якраз тут і виявляється відмінність між двома типами правопорядків, які базуються на офіційних і неофіційних правилах. Сукупність юридичних норм, обов'язкових для всіх членів цього суспільства або держави, що охороняються і захищаються всією силою і авторитетом групової або державної влади, П.О. Сорокін визначав як офіційне право певної групи або держави [12, с. 13]. Неофіційним правом він вважав правові переконання окремих груп, класів, професій і релігійних об'єднань, які існують у кожному суспільстві, правила пристойності, моди, релігійні норми поведінки, правила професії (лікарська, педагогічна, цехова), етики [12, с. 14].

Офіційне право не може охоплювати і визначати всі варіанти відносин у державно-організованому суспільстві, інакше воно було б неосяжним за своїм обсягом. За своїм змістом норми неофіційного права можуть збігатися з нормами офіційного права, а можуть і суперечити йому. Неофіційне право порівняно з офіційним правом зазвичай $\epsilon$ більш гнучким, більш рухомим, більш індивідуальним і стосується більш інтимних сторін людських взаємин. Тут якраз проявляється теза, озвучена вище: офіційний правопорядок, базований на чинних правових нормах, може загалом збігатися з правопорядком, який існує як неофіційний.

Існує три основних моделі інституційної взаємодії офіційного і неофіційного правопорядку. Перша, найкраща модель, полягає в тому, що офіційний і неофіційний правопорядки підтримують один одного, тобто вони $\epsilon$ нормативно тотожними, хоча інституційно можуть бути роз'єднаними. Друга модель полягає в тому, що між офіційним і неофіційним правопорядками існують свого роду «розриви», зумовлені відмінністю між тими правилами, які становлять основу офіційного чинного правопорядку, і тими правилами, якими реально

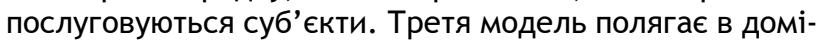
нуванні неофіційного правопорядку над офіційним, у результаті чого виникає так зване тіньове право.

Щодо першої моделі офіційний і неофіційний правопорядки формуються за рахунок співпадіння нормативних систем з одночасним розходженням інституційних систем. Як зазначає В.В. Завальнюк, «містком» між ними $\epsilon$ звичаєве право, яке одночасно має недержавне походження і державну санкцію [12, с. 13]. Однак не варто зводити звичай лише до одного із джерел права. Якщо сприйняти його у більш широкому контексті як модель поведінки, яка сприймається обов'язковою тими, хто їі відтворює, то стане очевидно, що коли офіційне право вимагає тієї ж поведінки, неофіційний правопорядок 
зміцнює офіційний і навпаки. Як підкреслює Дж. Раз, правило для того, щоб вважатися авторитетним, має базуватися на підставах, які вже існують у суспільстві і якими вже послуговуються люди [13, с. 212].

Важливою $є$ думка Ф.А. Хайєка, що навіть якщо правила, які утворюють встановлений (офіційний) правопорядок, і правила, які складають стихійний (неофіційний) порядок, збігаються чи то внаслідок інкорпорації неофіційних правил до правової системи, чи то внаслідок збігу вихідних підстав, якими керуються люди в усій своїй масі і законодавці - інституційно ці правопорядки не можу бути суміщені. Тобто, нормативна єдність офіційного і неофіційного правопорядку не може ототожнюватися чи вести до їхньої інституційної єдності.

Він підтверджує це таким аргументом: «стихійний порядок не тільки не можливо замінити організацією, зберігаючи при цьому можливість максимально використовувати розсіяне знання всіх його членів, але за допомогою прямих наказів його не вдасться навіть поліпшити або підправити. Використання такого поєднання стихійного порядку і організації завжди $€$ нераціональним»; “стихійний порядок виникає в результаті того, що кожен елемент цього порядку здійснює урівноваження діючих на нього сил і погоджує один з одним всі свої дії; однак якщо деякі дії стануть спрямовуватися іншою силою, яка прагне до інших цілей і враховує інші знання, цей баланс неминуче буде зруйнований» [14, с. 63]. На думку Ф. Хайєка, стихійний правопорядок як результат взаємодії великої кількості людей щодо різноманітних цінностей, підстав і причин для дій, у принципі завжди є більш ефективним і раціональним, ніж волевстановлений правопорядок, який іде «зверху». Іншими словами, інституціоналізація правопорядку - це завжди процес, який іде «знизу вверх».

Це не означає, що факт існування офіційного і неофіційного правопорядку робить офіційний правопорядок небажаним чи неефективним. Він $€$ таким лише у тому випадку, коли підстави і правила, що його формують, ідуть врозріз зі стихійним правопорядком або ж навіть переслідують мету зміни цього стихійного правопорядку через зовнішнє втручання. Однак якщо правовий порядок розвивається у спосіб, коли правила норми, що його складають, беруться $з$ неофіційного правопорядку, інкорпорують до тіла права, тобто коли цим правилам атрибутується чинність, то такий офіційний правопорядок, незважаючи на те, що він продовжуватиме бути лише одним із правопорядків, що існують у суспільстві, буде ефективним і авторитетним.

В окремих випадках офіційний правопорядок усе ж може якщо не створювати підстави для дій, то принаймні уніфіковувати ці підстави, які вже існують у рамках неофіційного правопорядку. Сила офіційного правопорядку полягає в тому, що за його допомогою відбувається уніфікація й інкорпорація підстав, що існують на рівні неофіційного правопорядку. В той же час така уніфікація повинна мати межі. Часто офіційний правопорядок повинен утримуватися від того, щоб інкорпорувати підстави, якими послуговуються суб'єкти на рівні неофіційного правопорядку, лишаючи простір для розсуду суб'єктів, зберігаючи продуктивний нормативний плюралізм.

Однак у будь-якому разі перша модель взаємодії офіційного і неофіційного правопорядків передбачає їх гармонійне поєднання, а не конкуренцію. Офіційний правопорядок не $\epsilon$ чимось зовнішнім чи ворожим щодо різноманіття неофіційних правопорядків, а радше певною частиною загального суспільного правопорядку, якому державою чи уповноваженим нею органом атрибутовано чинність. Це зумовлює нормативну єдність офіційного і неофіційного правопорядків із одночасною їхньою інституційною роз'єднаністю. Офіційний правопорядок, очолюваний державою, не може і не повинен підміняти неофіційний правопорядок в інституційному вимірі, тобто, беручи на себе функції, які краще реалізувалися неофіційними структурами.

Друга модель співвідношення офіційного і неофіційного правопорядку - це їх часткове неспівпадіння, коли офіційний правовий порядок встановлює обов' язки, що суперечать усталеним неофіційним практикам, або ж коли створює норми, які вступають у пряму конкуренцію з неофіційними нормами. В рамках другої моделі співвідношення офіційного i неофіційного правопорядку виникають розриви, які підривають ефективність і надійність офіційного правопорядку.

У більшості пострадянських країн можна бути свідками того, як офіційна система правил і процедур поступається неофіційним практикам, які не обов'язково $€$ неправомірними, однак підкреслюють низький рівень інституціоналізації офіційного правопорядку. Це як правило $€$ результатом відірваності правотворчості від реалій правового життя, коли сконструйований офіційний правовий порядок просто не вписується у вже існуючі практики і схеми людської діяльності.

Варто також мати на увазі, що часто офіційний правопорядок, йдучи врозріз із неофіційним правопорядком, сприяє встановленню більш гуманних чи справедливих соціальних практик. Так, часткове неспівпадіння офіційного і неофіційного правопорядку може мати як позитивні, так і негативні наслідки. 3 одного боку офіційний правопорядок може встановлювати більш високий стандарт поведінки і бути більш прогресивним, ніж неофіційні правові практики. 3 іншого боку це може підривати авторитет офіційного правопорядку, якщо неофіційні практики, хай навіть менш прогресивні, користуються вищим авторитетом і рівнем примусовості.

Третя модель характеризується найбільш суттєвими ризиками, а тому часто розглядається в якості так званого тіньового права. Офіційний правопорядок за такої моделі існує винятково як певна ідеальна модель, яка має небагато спільного з реальною ситуацією правової врегульованості відносин у тій чи іншій спільноті. Офіційний правопорядок може при цьому розцінюватися як легітимний з точки зору міжнародного співтовариства, а легалізовані ним органи влади можуть розглядатися як єдині легітимні представники народу. Однак при цьому він може мати нульову авторитетність і цілковито програвати в цьому сенсі неофіційному правопорядку.

Неофіційний правопорядок за такої ситуації може мати кілька проявів. Він може приводити до появи так званого тіньового права - альтернативної правової системи, яка існує незалежно від офіційних інституцій, але при цьому виконує більш-менш ті ж самі функції. Або ж він може призводити до інституційної фрагментації правопорядку, коли в рамках одного суспільства не формується однієї альтернативної правової системи, однак виникає певна їх кількість, яка охоплює визначене коло суб'єктів.

Оцінюючи тіньове право як однозначно негативне явище, В.М. Баранов зауважує кілька його ознак: 
тіньове право $\epsilon$ певним проявом юридичного плюралізму, коли держава не володіє виключною монополією на право, це різновид негативного неофіційного права, своєрідний звід обов'язкових приписів, конгломерат усних суджень, ритуалів, письмових установок, ритуалів, специфічних засобів захисту [15, с. 10]. Сутність тіньового права визначають як інституціоналізацію неправомірних варіантів поведінки, зумовлену нереалістичністю норм позитивного права з точки зору економічних можливостей і потреб суспільства, а також його ціннісних уявлень [16, с. 18]. Тіньове право може бути не тільки реакцією на неефективність та нереалістичність чинного законодавства, але й глибоко укоріненою традицією.

Ю.М. Оборотов підкреслює, що неправо - це правове втілення несвободи, пов'язане з використанням актуалізованої волі для досягнення індивідуальних і загально-соціальних цілей. Неправо неминуче демонструє обмеження свободи та свою далекість від всезагальної волі та всезагального права [17, с. 512]. Неправо $\epsilon$ формою права, а тому й породжуваний ним правопорядок так само $€$ порядком правовим. Особливої актуальності набуває розуміння того, що інституціоналізація такого правопорядку можлива лише за рахунок неспроможності держави підтримувати ефективність офіційного правопорядку на тому рівні, коли у суб'єктів права не виникає потреби використовувати різного роду тіньові практики для розв'язання своїх проблем.

Класичним прикладом, коли інституціоналізація неофіційного правопорядку призводить до утворення альтернативної правової системи, є ситуація в Сомалі. Як неодноразово підкреслювалося в резолюціях Ради Безпеки ООН щодо цієї африканської країни, неможливість встановлення офіційного правопорядку там зумовлена надзвичайною міцністю неофіційних бандитських практик, які хоча й здаються хаотичними війнами банд за ресурси, насправді виражають певну нормативну структуру, подібну до військової. Неофіційний правопорядок у Сомалі $\epsilon$ надзвичайно авторитетним серед його жителів. Фактично можна говорити, що кордонами «офіційного» правопорядку в Сомалі $\epsilon$ кілька урядових кварталів Могадішу, які охороняються військами [18]. Звісно, такі радикальні ситуації як у Сомалі, $є$ радше винятками. Однак вони показують, наскільки сильним може бути спонтанний неофіційний правопорядок, наскільки складно буває його витіснити волевстановленими рішеннями.

Менш радикальні, але більш поширені прояви інституціоналізації неофіційного правопорядку, які призводять до оформлення тіньового права, це поширені практики побудови нормативних систем всередині злочинних угруповань - практики, які часто стають предметом уваги кримінологів. Злочинне середовище $\epsilon$ так само підпорядкованим нормативним установкам як і незлочинне, хоча на рівні буденної свідомості це може здаватися нонсенсом. Насправді ж майже кожна більш-менш складна злочинна організація має власну нормативну систему, яка за рівнем розвиненості, інституційної спроможності й самодостатності може дати фору багатьом офіційним правопорядкам.

Такого роду приховані правопорядки, які існують за межею чинності, можуть створювати ризики для правової системи, тому зазвичай правова система прагне виробити бар'єри для інституціоналізації подібних пра- вопорядків. Однак процес стихійного нормоутворення контролювати практично не можливо, а тому ключовим аспектом співвідношення і взаємодії офіційного і неофіційного правопорядку в цій останній моделі (яка, очевидно, є найменш бажаною) має стати підвищення авторитету офіційного правопорядку і намагання зниження авторитету неофіційного правопорядку.

Висновки. Формування неофіційного правопорядку відображає ідею щодо інституціональної природи правового порядку в тому, що він не утворюється за рахунок встановлення норми сувереном, не $\epsilon$ результатом функціонування правової системи як такої, а постає як спонтанне утворення, яке будується «знизу вверх». У цьому сенсі розмежування між офіційним і неофіційним правопорядком може бути досить умовним і виражатися тільки тому, що офіційний порядок становить частину більш широкого простору правопорядку, а межею між ними $\epsilon$ чинність, тобто юридична обов'язковість норм.

Натепер у сучасних демократичних державах ефективний неофіційний правопорядок часто слугує потужним фактором відновлення легітимності офіційним правопорядкоеофіційний правопорядок може бути вагомим і цінним ресурсом у збагаченні офіційної правової системи тими нормативами, які демонструють свою легітимність серед суб'єктів права. Це, звісно, не означає, що неофіційні правопорядки, в яких домінують правила і цінності, несумісні з базовими засадами прав людини і верховенства права, не повинні ставати предметом ізоляції і деавторизації.

Загалом неофіційний правопорядок $\epsilon$ актуальною, живою, рухомою правовою матерією, сповненою ідеями та символами, які можуть живити офіційний правопорядок, посилювати його ефективність і легітимність. Одним із факторів зміцнення правової системи $\epsilon$ інституціоналізація як офіційного, так і неофіційного правопорядків, а подолання розривів між ними $є$ одним зі стратегічних векторів правової політики у сучасних демократичних державах.

\section{Література}

1. Скакун О.Ф. Теорія права і держави. К. : Правова $\epsilon$ нність, 2010. 525 с.

2. Загальна теорія держави і права / за ред. М.В. Цвіка, В.Д. Ткаченка, О.В. Петришина. Харків : Право, 2002. 432 с.

3. Борисов В.В. Правовой порядок развитого социализма. Bonросы теории. Саратов : Изд-во Сарат. ун-та, 1977. 408 C

4. Харт Г.Л.А. Понятие права. СПб : Издательство Санкт-Петербургского университета, 2007. 302 с.

5. Устав Организации Объединенных Наций и Статут Международного Суда. ВP України. URL: http://zakon4.rada.gov.ua/laws/show/995_010 (дата звернення: 10 жовтня 2019 року).

6. Горобець К. Концепт права: спроба системної інтерпретації. Філософія права і загальна теорія права. 2015. № 1-2. С. 211-223.

7. Эрлих О. Основоположение социологии права. СПб : Университетский издательский консорциум, 2011. 704 с.

8. Про Конституційний Суд України [Електронний ресурс] : Закон України від 13.07.2017 № 2136-VIII BP зі змінами, внесеними згідно із законами України, станом на 12.07.2018 № 2509-VIII // Електрон. дан. Режим доступу: http://zakon.rada.gov.ua/laws/show/.

9. Вестерман П. Чинність: репутація правил. Філософія права і загальна теорія права. 2016. № 1-2. С. 33-40. 
10. Уварова 0.0. Недержавне право: запрошення до дискусії. Право і громадянське суспільство. 2015. № 1. C. 14-32.

11. Горобець К. Чинність, авторитетність і репутація: рефлексії щодо статті П. Вестерман. Філософія права загальна теорія права. 2016. № 1-2. С. 41-52.

12. Завальнюк В.В. Офіційне та неофіційне право: антропологічне дослідження. Актуальні проблеми політики. 2014. Вип. 51. С. 12-21.

13. Raz J. The Morality of Freedom. Oxford : Oxford University Press, 1988. 434 p.

14. Хайек Ф.А. Право, законодательство и свобода: Современное понимание либеральных принципов справедливости и политики. М. : ИРИСЭН, 2006. 644 с.

15. Баранов В.М. Теневое право как антиюридическая жизнь. Юридическая наука и практика. 2014. № 4. С. 9-21.
16. Калинин А.Ю. Теневое право с позиций структурнофункционального подхода. Юридическая наука и правоохранительная практика. 2011. № 4. С. 16-20.

17. Оборотов Ю.М. Неправо. Велика українська юридична енциклопедія. Харків : Право, 2016. Т. 2 / ред. С.І. Максимов. С. 512-515.

18. Report of the Secretary-General on Somalia: UN Security Counicl Resolution S/2016/751. URL: http: / / www. securitycouncilreport.org/atf/cf/\%7B65BFCF9B6D27-4E9C-8CD3-CF6E4FF96FF9\%7D/s_2016_751.pdf.

Крижановська О. В., orcid.org/0000-0002-3423-6682 кандидат юридичних наук, викладач кафедри адміністративної діяльності поліції одеського державного університету внутрішніх справ 